Journal of American Studies, 49 (2015), 3, 575-592 C Cambridge University Press 2014. This is an Open Access article, distributed under the terms of the Creative Commons Attribution licence (http://creativecommons.org/licenses/by/4.o/), which permits unrestricted re-use, distribution, and reproduction in any medium, provided the original work is properly cited.

doi:10.1017/S0021875814001303 First published online I 3 August 2014

\title{
"Too many goddamn echoes": Historicizing the Iraq War in Don DeLillo's Point Omega
}

\author{
MARTIN PAUL EVE
}

This piece provides a detailed engagement with Don DeLillo's depiction of the 2003 Iraq War in his latest novel, Point Omega. Framed through both formal aesthetic signposting of the interrelations between modernist and postmodernist practice and also through explicit thematic comparison between the conflicts, I trace DeLillo's treatment of Iraq in Point Omega back to his earlier writing on the Cold War in Underworld and focus upon the ways in which this comparative historical metaphor can be read with particular emphasis upon its implications for the nation-I state.

Wherever one's political sensibilities lie in relation to the 2003 Iraq War there is a different mode of politics with which it seems imperative that all who value art must continue to engage: the politics of representation. Indeed, the act of representing war and individual, lived, real horror is intensely problematic and raises ethical issues that are well framed in Theodor Adorno's widely known remark that "the aesthetic principle of stylization ... [makes] an unthinkable fate appear to have had some meaning ... something of its horror is removed." While this stance clearly shows a problem with the aesthetic and stylized representation of war, another larger problem lurks, of which Adorno's remark is merely one instance: historical and experiential relativism. ${ }^{2}$ When comparing conflicts, either metaphorically or directly, it is important to ask whether we have the right to degrade the specificity of that singular horror through analogy, or whether the terror of wartime experience is absolute to those who lived it. Furthermore, if answering in the vein of the latter, we must then ask how we can avoid a space of non-empathic silence,

Department of English, University of Lincoln. Email: martin@martineve.com.

I Theodor W. Adorno, "Commitment," in Aesthetics and Politics, trans. Francis McDonagh (London: Verso, 2007), I77-95, I89.

${ }^{2}$ It is important to note that I am using "relativism" here in its stricter sense, not to mean an equal privileging of every compared aspect (as in the dangers of moral relativism), but rather as a term denoting a phenomenon's comparison and relativistic character. To compare one conflict with another is to relativize both: to put aside, even if only temporarily, the absolute specificities and unique characters of each event. 
one caught between the dead and the unknowing living, where only the absolutist (and non-communicable) experience of survivors remains.

Responding to these problems remains difficult but some progress is made in Georges Bataille's "Lectures on Nonknowledge," wherein notions of a consciousness within tragedy undertaking a "search for the most perfect silence" are explored. ${ }^{3}$ Amid tragedy's search for silence, Bataille concludes that it is only truly possible to grasp tragedy within an exegetical framework:

It is therefore a question of knowing if my presentation does not have, in turn, an advantage over tragedy. The correction of my presentation will consist in this knowledge.

Of course, I am starting from my powerlessness to present what I would like to talk about. But, though tragedy itself cannot, I can talk about the consequences of the representation of tragedy for each of us. The silence that follows tragedy is proper to it, and without doubt this is still, in my opinion, an advantage of tragedy. It is not explained. Here, meanwhile, in the absence of explanations of tragedy I can offer an advantage in this sense: tragedy that is not explained is still at the mercy of explanations. The tragic author does not explain himself, but he is defenseless against the explanations of others. In order to suppress explanation it is not sufficient to not give any. The human mind is made such that tragedy does not take place without instruction, without any consequences. ${ }^{4}$

From this arises the twofold notion that tragic representation must be a search for the perfect silence that allows the (non-)expression of its true (absolute) horror while simultaneously being a form that is situated within (relativistic and stylizing) exegetic discourse. In the literary realm, it is clear that the process of working towards this "point after which there is nothing to say"s has been most prominently explored in the limit-modernist prose of Samuel Beckett's The Unnamable and Worstward Ho. Of more relevance for the matter that I wish to explore here, however, is that it has been clear for some time now that the works of Don DeLillo contract dramatically towards minimalism around the millennial break and seem also to pursue such a quest for silence.

The aesthetic telos of DeLillo's novels is best described in terms of a formal career-long movement from postmodern play, through to quasi-encyclopedicism to a contracted minimalism. From his clearly Pynchonian phase in Ratner's Star, the texts shift to Libra and Underworld's grand explorations of history, film and American culture. Around the turn of the new century, however, DeLillo migrates his attention, at least in some ways, to a politicized focus on terrorism and the Iraq War. The contraction exhibited at this moment, and most prominently so in DeLillo's latest novel, Point Omega,

\footnotetext{
${ }^{3}$ Georges Bataille, "The Teaching of Death," in Stuart Kendall, ed., The Unfinished System of Nonknowledge, trans. Michelle Kendall and Stuart Kendall (Minneapolis: University of Minnesota Press, 2001), I 19-28, I 22.

${ }^{5}$ Georges Bataille, "Nonknowledge," in ibid., 196-205.
} 
reads as a form of withdrawal: an implosion headed for extinction, for the omega point after which there is nothing to say. Indeed, this aspect is framed in multiple meta-narratorial comments throughout the text. From the perspective of Richard Elster, for example, it is the case that " $t \mathrm{t}]$ he true life is not reducible to words spoken or written." Likewise, from an abstract narrative perspective, DeLillo's novel positions its own mission statement in terms of a "language that's struggling toward some idea outside our experience", 7 echoing its omega title: "This was the point." ${ }^{8}$ Concurrent to this search for silence, however, and core to the argument that I will set out here, is that there is also a strong historical relativism within Point Omega that is enacted through DeLillo's back-reference to the Cold War and his previous, maximalist novel Underworld; an aspect that sits in tension with the quest for tragic silence that the text otherwise structurally proclaims.

In this article, probing the politics of representation and affinities with limit-modernism, I want to think through some of the ways in which these tensions between absolutism and relativism (in the senses of both historical analogy and epistemological privacy) play out in the text. At the same time, I want to unearth the contradictions that are exposed in such a reading, most notably in the role of the nation-state. I will also here explore how the anachronistic comparison of the Cold War to the second Iraq War yields readings of DeLillo's earlier fictions that cannot be understood as specifically about the Iraq War but that nonetheless seem to structurally presage it. These explorations will be conducted over three sections: an analysis of DeLillo's formal structures and histories, an examination of DeLillo's intertextuality as it pertains to the Cold War, and a final section detailing the political consequences of these aesthetic choices.

Although Peter Boxall has already framed the way in which prophetic coincidences in DeLillo's works should not be read as important for the specific details that are later validated, but for their understanding on a historiographic level, John N. Duvall puts it more bluntly: they are "eerily prescient." While my claims for prophetic insight will be less grand, one of the core contradictions that I will explore in this article is that although the historiographic passages in Point Omega signpost a situation in which the nation-state is no longer the privileged agent of war, they also simultaneously indicate a specific return to, or persistence of, a mode of strong state-driven international conflict. Furthermore, I will argue, although Point Omega is also

\footnotetext{
${ }^{6}$ Don DeLillo, Point Omega (London: Picador, 2010), 17. $\quad{ }^{7}$ Ibid., $72 . \quad{ }^{8}$ Ibid., 5-6.

9 Peter Boxall, Don DeLillo: The Possibility of Fiction (London: Routledge, 2006), I 58 ; John N. Duvall, "Witnessing Trauma: Falling Man and Performance Art," in Stacey Michele Olster, ed., Don DeLillo: Mao II, Underworld, Falling Man, Continuum Studies in Contemporary North American Fiction (London: Continuum, 201 I ), I 52-68, I 54.
} 
firmly rooted in the United States, the overlayed metaphor of the American desert (for Iraq) does much to redress earlier criticisms of US-centrism, such as those made by John Carlos Rowe, by blurring inside and outside perspectives while also querying the role of the state(s). ${ }^{\circ}$ It is similarly important to note, however, that the aesthetic forms through which DeLillo frames this are not mere sideshows, and require attention for their own politics. As Duvall has noted, since The Body Artist DeLillo has placed an emphasis on finding the way in which "art might still vie with terrorism." I In the light of Point Omega, it remains imperative to assess, and begin with, DeLillo's politicized aesthetics.

\section{MODERNISM, FORM AND POINT OMEGA}

Set in what Alexander Dunst has referred to as a "traumatized present," Point Omega begins with an unknown man's visit to the Museum of Modern Art, where he has come to view Douglas Gordon's installation 24 Hour Psycho. ${ }^{12}$ This film is, as its name suggests, a version of Alfred Hitchcock's classic horror piece stretched to run over a day-long period. This episode is, however, "merely" an enigmatic frame to the main action of the novel, which concerns the visit of a filmmaker to Iraq War strategist Richard Elster. In the latter portion of the text, Elster's daughter Jessie disappears without a trace, although it is probable that Jessie's disappearance is linked to her meeting with the unknown viewer of the Gordon installation. The novel ends without resolving the mystery of Jessie's disappearance for the reader.

Interestingly, Point Omega contains, at a microscopic, compressed level, many of the elements that have featured throughout DeLillo's entire canon and it is therefore worth beginning with some remarks on aesthetic form and periodization that are integral to the reading of Iraq in DeLillo's work to which I wish to progress. ${ }^{13}$ To begin this, it is curious to note that DeLillo's novel has been described as "modernist" by various commentators. While such category terms as "modernism" and "postmodernism" are fluid and will never fully hold, Point Omega can be seen as "modernist" in so far as a subset of this field is defined by notions of prose experiment paired with an extreme minimalism. ${ }^{14}$ Indeed, with echoes of Beckett's Ghost Trio's "door

${ }^{10}$ John Carlos Rowe, "Global Horizons in Falling Man," in Olster, Don DeLillo, I 2 I-34, I 34.

${ }^{11}$ Duvall, ${ }_{156 .}$

${ }^{12}$ Alexander Dunst, "After Trauma: Time and Affect in American Culture Beyond 9/I I," Parallax, 18, 2 (2012), 56-71, 60.

${ }^{13}$ While using "Iraq" as a metonymic shorthand for "the Second Gulf War" could be considered problematic, I here use the formulation for reasons of economy.

${ }^{14}$ A lineage that David James traces in Morrison and Coetzee from late Beckett. David James, Modernist Futures: Innovation and Inheritance in the Contemporary Novel (New York: Cambridge University Press, 2012), 22. 
imperceptibly ajar," the prose in this novel has, as Cowart puts it, a style indebted to a "modernist aesthetic that married a high standard of economy to new representational challenges." Is This can be seen in the novel's focus on the (in)visible, but also in its rhythm and tone, from the very beginning: "There was a man standing against the north wall, barely visible. People entered in twos and threes and they stood in the dark and looked at the screen and then they left." ${ }^{16}$ Another instance of this follows shortly after: "The guard was here to be unseen." ${ }^{17}$ Although DeLillo's works have always had this propensity to experiment with staccato, interjected forms - one recalls the memorable mid-sentence "Mastercard, Visa, American Express" in White Noise ${ }^{18}$ - and have also frequently held sway for their uncanny ability to replicate conversational dynamics through cross-purpose, disintegrated dialogue, Point Omega nonetheless seems extreme in its retreat to "modernist" economy (as Cowart frames it), even explicitly offering up a high-modernist maximalist reference point at one moment with the Molly Bloom-esque phrasing of "I said yes ... I said yes ... I said yes." ${ }^{9}$

Where James's argument of a reinscription of modernist practice falls a little short, though, and especially so when reading DeLillo, is in his somewhat scathing references to "postmodernism" as a catchall term for "politically abortive metafiction." ${ }^{2 \circ}$ Certainly, it is true that some forms of "postmodern" fiction could fall into this bracket and that DeLillo's brand of postmodernism is characterized, at least in part, by metafictional strategies. ${ }^{21}$ However, far from being politically abortive, metafiction is also a critical distancing apparatus that can be seen in affinity with Brecht's Verfremdungseffekt; at once a modernist legacy and concurrently a sociopolitical and ethical practice framed through a direct terminological link to Marx's theory of Entfremdung. ${ }^{22}$ This is important for the line that I am going

${ }^{15}$ David Cowart, "The Lady Vanishes: Don DeLillo's Point Omega," Contemporary Literature, 53, I (2012), 3 I-50, 3 I. $\quad{ }^{16}$ DeLillo, Point Omega, $3 . \quad{ }^{17}$ Ibid., 7.

${ }^{18}$ Don DeLillo, White Noise (London: Picador, 1986), 1 00.

${ }^{19}$ DeLillo, Point Omega, 99- 1 oo. This allusion to Ulysses surely complicates a situation of Point Omega's "modernism" within a solely minimalist framework and further exemplifies the difficulty of deploying such labels.

${ }^{20}$ James, IO. It is also notable that James's choice of texts in this eloquent volume - notably Conrad, Ford and James - seems to imply a specific bent of impressionistic modernism that at times does not quite capture the most popular understanding of high modernist experiment centred around 1922.

${ }^{21} \mathrm{John}$ Barth, as the most notable example, pushed postmodern metafictive practice to its logical conclusion and exhausted the form, even if diehard adherents might suggest that Giles Goat-Boy, among other works, remains a biting political satire that can hardly be deemed amoral.

${ }^{22}$ This is noted by Patricia Waugh. See Patricia Waugh, Metafiction: The Theory and Practice of Self-Conscious Fiction (London: Methuen, 1984), 152. It is necessary to point out, however, that in Waugh's reading this estrangement discredits political interpretations. 
to pursue here because, at the same time as deploying these modernist aesthetic traits (as far as they are "modernist" and as far as such labels matter or are helpful), DeLillo deliberately evokes postmodern metafiction in a looped repeat of his earlier novels. ${ }^{23}$ This reference to DeLillo's earlier career phase is achieved through two metafictional strategies. The first is through directly metafictional statements about the slender Point Omega, in a mode evocative of Ratner's Star, when the text remarks, "The less there was to see, the harder he looked, the more he saw." ${ }^{24}$ The second is through the intertextual allusions to the ultra-slow film epochs of rocks in Thomas Pynchon's Gravity's Rainbow - a seminal text of postmodernism where "We're talking frames per century," 25 mirroring Richard Elster's experience in "geologic time" 26 of 24 Hour Psycho: "He told me it was like watching the universe die over a period of about seven billion years." 27

Moving beyond stylistic aesthetics, though, the novel also cycles back, importantly, towards a postmodern ontological indeterminacy that forms the point of overlap with modernist epistemological issues; as already noted, the reader is never given enough evidence to uncover what has happened to Jessie or what has caused her disappearance, only strongly suggestive clues and forking paths. ${ }^{28}$ Through these three aspects - metafictional commentary, ontological indeterminacy and DeLillo's intra-corpus intertextuality - it is clear that a postmodern heritage must play at least some role in a reading of Point Omega's generic style. From this base, and to explore this further, I would now like to suggest that through DeLillo's intertextuality within his own corpus - an aspect that is initially signposted through a weak stylistic affinity with his earlier works, despite the fact that Point Omega appears superficially to be minimalist and "modern" - emerges a complication for politicized readings of his text and its thematic subject areas.

${ }^{23}$ Although a definition of "postmodern" metafiction is elusive, I am broadly referring to selfreflexive fictions written between the late I950s and the early I990s, often with a focus on the constructed nature of history in the vein of Linda Hutcheon's historiographic metafiction. See Linda Hutcheon, A Poetics of Postmodernism: History, Theory, Fiction (New York: Routledge, 1988).

${ }^{24}$ DeLillo, Point Omega, 5.

${ }^{25}$ Thomas Pynchon, Gravity's Rainbow (London: Vintage, I 995), 6 I 2.

${ }^{26}$ DeLillo, Point Omega, 19.

${ }^{28}$ For a good discussion of how ontological and epistemological uncertainties feed into modernist and postmodernist discourses see Brian McHale, "Change of Dominant from Modernist to Postmodernist Writing," in Douwe W. Fokkema and Hans Bertens, eds., Approaching Postmodernism, Utrecht Publications in General and Comparative Literature, 2 I (Amsterdam: John Benjamins Publishing, I986), 53-79. 


\section{THE COLD IRAQ WAR: DELILLO'S INTRA-CORPUS INTERTEXTUALITY}

In addition to the affinity with ontological and epistemological indeterminacies that connect Point Omega to earlier novels such as Underworld and Ratner's Star, there are other more specific textual allusions to DeLillo's oeuvre embedded in his later work. The most striking of these, to begin with, is a disturbing undercurrent of implied sexual violence that is achieved through a connection of Jessie's disappearance to DeLillo's more recent short story "Baader-Meinhof." In this story, a woman at a gallery (viewing the Gerhard Richter paintings of the Baader-Meinhof Gang) goes home with a sinister man whom she then has to lock outside her bathroom as the scene degenerates frighteningly close to a sexual assault. However, sexual violence also features as a clear subtext in Point Omega, as it does in the case of any contemporary abduction. This is heightened in this instance when the unknown gallery character in the novel "imagined turning and pinning her to the wall," 29 thereby once more linking sexual violence to an art exhibition. Meanwhile, in another clear instance of negating paradigms of nonknowledge, Jim Finley narrates all the sexual fantasies of Jessie that he didn't have. ${ }^{\circ}$ The strange situation of indeterminacy engendered by the narration of fictional sexual fantasies that the narrator claims he did not have has ethicopolitical significance in its reference to "Baader-Meinhof." This is because, in the short story, there is a clear representation of misogynistic sexual violence in thematic juxtaposition with armed conflict, terrorism and art. This is also directly the case in Point Omega, as, to some extent, the text is concerned with the Iraq War. Consider, for instance, the significance of the fact that, at one moment in the novel, the narrator questions whether Richard Elster's assertion is correct "that the country needed this [Iraq], we needed it in our desperation, our dwindling, needed something, anything, whatever we could get, rendition, yes, and then invasion." ${ }^{31}$ This is neither only proximal to Jim Finley's voyeurism nor solely framed by the presumed sexual violence of the Gordon exhibition, but is itself a sexualized phrasing: its "needs"; its quasiorgasmic, comma-delimited "yes"es; its "desperation" and "invasion." And all, of course, in conjunction with the disappearance of a woman in the desert.

This statement of need is also important, however, because it is an almost direct echo of Marvin Lundy's assertion in DeLillo's earlier novel, Underworld, that "the Cold War is your friend ... You need it to stay on top ... the whole thing is geared to your dominance in the world." 32 Furthermore, this is not the only seemingly direct allusion to Underworld in Point Omega. The persistent

\footnotetext{
${ }^{29}$ DeLillo, Point Omega, i 12.

${ }^{32}$ Don DeLillo, Underworld (London: Picador, I998), I70-71.
} 
references to "the man at the wall" 33 (referring to the man in the gallery) intersecting with the name of Jim Finley's anticipated film documentary, "Man at the wall," or "Up against the wall," 34 create a strong resonance with the original title of Underworld's opening sequence: "Pafko at the Wall." In addition to this, DeLillo deploys a double-layered critique of the length of his previous books in Elster's assertion that "An eight-hundred-page biography is nothing more than dead conjecture," a difficult passage to decode because it is unclear how Elster's problematic placement within the text as a war apologist can permit him to make uncontaminated metatextual statements (hence double-layered). ${ }^{35}$ Point Omega also frames Finley's previous documentary effort in terms of fragments, "assembled completely from documents, old film footage, kinescopes of TV shows from the I950s ... edited well beyond the limits of information and objectivity and not itself a document," which, alongside a focus on a comedian, as with Underworld's Lenny Bruce sections, sounds eerily similar to Underworld's methodology, with its pop-culture bricolage of "Long Tall Sally," "Cocksucker Blues" and so forth. ${ }^{36}$

Continuing this hunt for references to the imagery of Underworld it soon becomes apparent that Cold War themes are omnipresent in the novel with hints at a dialectical structure of US-Russian reconciliation and antagonism provided through Jessie's mother, Elster's ex-wife, who is Russian. Through this, Jessie becomes the Cold War child: half-American and "self-determined," but half-Russian, "another life, nowhere near mine." 37 In short, for the American Elster, his ex-wife, the Russian, is "a gorgeous woman, even today, but bad blood persists between us." 38 Allied with notions of "little nuclear flirtations," 39 the narrator-figure/Jim describes the zone where Jessie is suspected to have disappeared as the "Impact Area," thereby clearly linking to notions of heavy ordnance and desert-based nuclear testing. ${ }^{\circ}$ Notably, however, while it can be seen that there are clearly many allusions to Underworld in Point Omega, despite the slimness of the latter, DeLillo does not frame this explicitly. This can perhaps be explained by reference to a question that Jim asks in the novel: "Because how would it make him feel, being a successor, a straight man to a rampaging comic?" ${ }^{4}$ This structure of constant reference does, though, bring the issue of the Cold War back into the spotlight.

Indeed, if, as a hypothesis from these observations, one ventures that DeLillo's persistently rendered fear or hope across the period between these

\footnotetext{
${ }^{33}$ DeLillo, Point Omega, 4.

${ }^{34}$ With its implied, subvocalized, unfinished anarchist suffix that is only later explicitly articulated: "motherfuckers." Ibid., 45.

${ }^{36}$ Ibid., 25.

39 Ibid., 50. $\quad{ }^{40}$ Ibid., 9 I.

35 Ibid., 17.

${ }^{38}$ Ibid., 58.

${ }^{41}$ Ibid., 27.
} 
two novels, Underworld and Point Omega, is the approaching end of a USdominated world - signalled in the novels threefold through direct statements of a worried "need" for superiority; structural, formalist methods; and more conventional modes of intertextual reference - the function of the comparison between Iraq and the Cold War must be considered. It must also be noted, at this juncture, however, that the second Iraq War, like Afghanistan before it, was a national conflict predicated on subnational terrorism and the notion of the "rogue state." 42 Ostensibly, the US State Department's rationale was the removal of "a regime that developed and used weapons of mass destruction, that harbored and supported terrorists, committed outrageous human rights abuses, and defied the just demands of the United Nations and the world." 43 It is surely unnecessary to point out the hypocrisy of such a rationale given that the invasion was launched in contravention of the United Nations Charter and deemed illegal by the UN Secretary, Kofi Annan. ${ }^{44}$ It is also surely unnecessary to say that subsequent claims for weapons of mass destruction and any evidence of cooperation with al Qaeda were disproved. ${ }^{45}$ What now needs careful exploration, however, is the exact nature of the comparison that DeLillo makes to the Cold War, across this multiply positioned, rehistoricized, sub- or internationally justified, even if falsely, Iraq War.

In order to further explicate these structural back-references to Underworld and the Cold War, it is necessary to examine several aspects of the sociohistorical backdrop against which the text is set, beginning with the subnational component of the Iraq War: Iraq as the base for al Qaeda, the ongoing "war on terror." According to the US State Department, in a paper entitled "Patterns of Global Terrorism" published in the year 2000, terrorism is "premeditated, politically motivated violence perpetrated against noncombatant targets by subnational or clandestine agents, usually intended to influence an audience." 46 Contrast this with the definition presented by

42 "Subnational" is here referring to the size of the agent, rather than any kind of geographical bounding. Subnational agents are also, frequently, trans- or supernational.

${ }^{43}$ US State Department, "Winning the War on Terror," 2003, at http://200I-009.state.gov/ documents/organization/24172.pdf.

44 "Iraq War Illegal, Says Annan," BBC, 16 Sept. 2004, sec. Middle East, at http://news.bbc.co. $\mathrm{uk} / \mathrm{I} / \mathrm{hi} /$ world/middle_east/366 I I 34.stm.

${ }^{45}$ R. Jeffrey Smith, "Hussein's Prewar Ties to Al-Qaeda Discounted," Washington Post, 6 April 2007, sec. Nation, at www.washingtonpost.com/wp-dyn/content/article/2007/04/05/ AR2007040502263.html.

${ }^{46}$ Cited in Glenn E. Schweitzer and Carole Dorsch Schweitzer, A Faceless Enemy: The Origins of Modern Terrorism (Cambridge, MA: Perseus, 2002), 3 I. Note that several portions of this section are reiterations and refinements of an argument that I have made previously in Martin Paul Eve, "It Sure's Hell Looked like War': Terrorism and the Cold War in Thomas Pynchon's Against the Day and Don DeLillo's Underworld," in Zofia Kolbuszewska, ed., Thomas Pynchon and the (De)vices of Global (Post)modernity (Lublin: Wydawnictwo KUL, 2013), 39-53. 
Christopher Harmon, a theoretician, as opposed to a policymaker: "Terrorism is the deliberate and systematic murder, maiming, and menacing of the innocent to inspire fear for political ends." 47 The most important distinction between these definitions for the purpose at hand is the inclusion of a clause specifying that terrorism can only be perpetrated by "subnational or clandestine agents." As with the post-World War II International Military Tribunal (IMT) in Nuremberg, in which the charges were specifically crafted to ensure that the atomic bombings could not be construed as war crimes, this definition of terrorism guarantees that any acts committed by a state cannot be considered as acts of terror.

These facets are all of interest in relating the function of the state to the subnational actor, an aspect to which I will return in DeLillo's earlier novels, but especially so when it is considered that Larry Diamond, a senior fellow at Stanford, noted in 2002 that the "political struggle against international terrorism has many of the features of a new Cold War." 48 Echoing DeLillo's metaphorical parallels between the contemporary moment of Point Omega's implied Iraq and Underworld's implied Russia, Diamond also refers to jihadist terrorists as the "Islamic Bolsheviks" while mapping parallels between their levels of education and that of Russian revolutionaries, specifically Lenin. This metaphorical parallel between the Cold War and the Second Gulf War is one whose prevalence is growing. In early 2013, Tony Blair deployed exactly the same terminology in an interview with The Guardian newspaper, likening the fight against terrorism to the Cold War. ${ }^{49}$

This is a troubling analogy for several reasons which, as shall be seen, are key to DeLillo's fiction. First, it is clear that recent divergent atrocities are being amalgamated as though their historical specificity was of no importance; terms such as "terrorism," "jihad" and "revolutionary terrorism" are used interchangeably, regardless of complex socioeconomic factors that could affect such a conflated judgement, thereby exhibiting the problematic paradigms of relativism laid out at the beginning of this article. Second, this conflated notion of a war on terrorism is being used to equate leftist thought against the state ("revolutionary communism") with violent terrorism ("revolutionary terrorism") - an irony given that the term "terrorism" was coined in relation to state violence during France's Reign of Terror but important for the link to DeLillo's "Baader-Meinhof." It should also be remembered that the function

${ }^{47}$ Christopher C. Harmon, Terrorism Today, 2nd edn (London: Routledge, 2008), 7.

${ }^{48}$ Larry Diamond, "Winning the New Cold War on Terrorism: The Democratic Governance Imperative," Institute for Global Democracy Policy Paper No I, March 2002, 2.

${ }^{49}$ Press Association, "Blair: Fight against al-Qaida Could Last a Generation," The Guardian, 3 Feb. 2013, at www.guardian.co.uk/world/2013/feb/03/blair-fight-against-alqaida-generation. 
of such comparison is clearly ideological at the linguistic level and rests on the previous legitimation (or otherwise) of past conflicts. It may well be trite to use the cliché that one man's freedom fighter is another's terrorist - and this type of crude binary logic does disservice to pacifist movements who have successfully resisted and implemented change without recourse to militancy but there are clear ideological motives for the use of specific terminologies by those who have waged war without the sanction of the international community from centre-right political ground. This Cold War comparison, in other words, serves a bidirectional delegitimation function, in much the same way as the battle was fought over the terms "Red Army Faction" (legitimating) and "Baader-Meinhof Gang" (illegitimate) in I960s Germany. It serves to discredit contemporary terrorist movements, implicitly, and past leftist movements, explicitly. Interestingly, as I will now go on to show before concluding this section, this comparison also draws out the fundamental contradictions in small-state neoconservative ideology.

Curiously, the primary function of DeLillo's comparison between the Cold War and contemporary conditions of terrorism seems to be to continue to cast the state as a key actor in international conflict, in contrast to theorizations of new, simultaneously sur- and subnational, entities, such as those found in Hardt and Negri's Empire. Indeed, this is why it is interesting to continue to read DeLillo in terms of postmodernism, for, in that work, the authors note that

[m]any of the concepts dear to postmodernists and postcolonialists find a perfect correspondence in the current ideology of corporate capital and world market. The ideology of the world market has always been the anti-foundationalist and anti-essentialist discourse par excellence ... As the world market today is realized ever more completely, it tends to deconstruct the boundaries of the nation-state. ${ }^{50}$

It is curious, then, that right-wing policy hawks, such as DeLillo's Elster - who champion the market and supposedly eschew state intervention (although see David Harvey for some doubts on this front $\mathrm{t}^{\mathrm{s}}$ ) - should nostalgically and strongly reinscribe the role of the state in a narrative of otherwise post-national forces.

Such points must be considered in relation to DeLillo's fiction, I contend, because Underworld and the later Point Omega both seem to be situated within this comparative discourse - ranging from Iraq and terrorism to the Cold War - which is of especial interest given that Underworld pre-dates the later conflict. However, while it is impossible for Underworld to have foreseen

\footnotetext{
${ }^{50}$ Michael Hardt and Antonio Negri, Empire (Cambridge, MA: Harvard University Press, 2000), I 50.

${ }^{51}$ David Harvey, A Brief History of Neoliberalism (Oxford and New York: Oxford University Press, 2007).
} 
the catastrophic events of September I I, 200 I, and while DeLillo's earlier text on the Cold War admirably depicts the conditions that produced that event, the political rationale that the author gives, in several locations, for a connection between the two is that a nostalgia for strong, state-driven conflict is to blame. Indeed, in his post-9/ i essay, "The Ruins of the Future," DeLillo suggested that a major contribution to these conditions must be attributed to the Bush Administration's "nostalgia for the Cold War," a fascination that ended "in the rubble." 52 In addition to this, DeLillo also wrote of the urgent need to abandon the "Us and Them" dichotomy, a divide that was already being dismantled in Underworld through the presentation of the state as a terrorist. This is a topic that has already been touched upon by Linda Kauffman, who notes that terrorism "is inside us all - not just individuals, but nations," connecting this to "the Nazis" and the post-9/I I American governmental policies of "renditions, Guantanamo, Abu Ghraib, and a gulag of secret prisons." 53

One of the best examples of this alternation of representation between state and terrorist is found in Underworld's depiction of the so-called "Texas Highway Killer." In a clear reference to the assassination of President Kennedy, which DeLillo explores more extensively in Libra, several of the murders are captured on film, to the delight of the media outlets who run the footage repeatedly. ${ }^{54}$ These same media outlets also provide a voice for the Killer to distance his practice from the stereotypical madman, the insane murderer: "Let's set the record straight. I did not grow up with head trauma. I had a healthy, basically, type childhood." 5 s This fits well with Gus Martin's assessment of the mainstream, lay, opinion on the logic of terrorism:

This presumption suggests that terrorism is a priori ... irrational behaviour and that only deranged individuals ... would select terrorist violence as a strategy. Most experts agree that this blanket presumption is incorrect ... their behaviour is neither insane nor necessarily irrational. ${ }^{6}$

Such a stance holds up well against a comparison to the threat of nuclear war. Both nuclear war and the terrorism of the individual actor here emerge from rational beginnings: a desire for a deterrent or a typical childhood; both situations also result in violent actions: the policy of mutually assured destruction and the murder campaign of the Highway Killer; and both situations finally resolve beyond their rational origins in a self-negating

52 Don DeLillo, "In the Ruins of the Future: Reflections on Terror and Loss in the Shadow of September," Harper's, Dec. 200 I, 33-34.

${ }^{53}$ Linda S. Kauffman, "The Wake of Terror: Don Delillo's 'In the Ruins of the Future,' 'Baader-Meinhof,' and Falling Man," Modern Fiction Studies, 54, 2 (Summer 2008), 353-77, 360. $\quad{ }^{54}$ DeLillo, Underworld, i $55 . \quad 55$ Ibid., 216.

${ }^{56}$ Gus Martin, Essentials of Terrorism: Concepts and Controversies (Los Angeles: Sage, 2008), 48. 
dialectic: an arms race beyond all logical hope and an inability to answer the media's insistent questioning: "Why are you doing it?" 57

It seems clear, as I have already argued elsewhere, that DeLillo's pre-9/ I I novels, particularly Underworld, situate subnational terrorism and acts of violence within Cold War metaphors and similes that complicate the stateterrorist binary..$^{8}$ Before coming back to an assessment of how this rendition sits within the framework of problems laid out above, however, it is necessary to finally examine the way in which Iraq 2003 is explicitly depicted in Point Omega along the same axis: the representation of the nation-state.

Iraq, to the extent that it appears in DeLillo's novel, is represented both through Richard Elster, the war apologist, and through the key, glaring metaphor for the war: that he loses his daughter in the desert ("The desert was outside my range, it was an alien being" 59 ), never fully understanding why. Behind this consideration of landscape, however, lie the statements that DeLillo gives to Elster on the nature of the Iraq War. First, in addition to the structural tension of form already outlined, DeLillo plays on his Baudrillard-infused earlier novel White Noise with the lament of Elster that "their war is acronyms, projections, contingencies, methodologies ... Their war is abstract." 60 In some senses here, the Iraq War Did Not Happen Again; the environment is explicitly virtualized. Second, leading on from this, in Elster's warped apologist stance, the true nature of the Iraq War is filmic: "Lying is necessary. The state has to lie. We went beyond this. We tried to create new realities overnight ... These were words that would yield pictures eventually and then become three-dimensional." ${ }_{1}$ This is a distinctly postmodern reality-from-art perspective reminiscent of Pynchon's German expressionist film director von Göll and here seems to empower artworks, or fictions, an aspect that has featured continuously throughout DeLillo's career. ${ }^{62}$ Third, war is future-orientated in DeLillo's novel: "A great power has to act. We were struck hard. We need to retake the future. The force of will, the sheer visceral need. We can't let others shape our world, our minds."63

This depiction, garnered from just one conversation with Richard Elster, yields a virtual war that sprang from deceptive, reality-sowing illusions and which is driven, crucially, by the state. This yields, therefore, a twofold wavering in Point Omega between, first, a national level of warfare predicated on "great powers," "the state" locked in battles of will in order to shape the future, and, second, a more decentralized form of abstraction. This second feature becomes clearer when DeLillo's work moves on to provide information on one of Elster's academic pieces; a study of the etymology of the word

\footnotetext{
${ }^{57}$ DeLillo, Underworld, 216.

${ }^{59}$ DeLillo, Point Omega, 20.

${ }^{58}$ Eve, "It Sure’s Hell Looked Like War."

${ }^{60}$ Ibid., 28.

${ }^{61}$ Ibid., 28-29. $\quad{ }^{62}$ Duvall, "Witnessing Trauma," i $53 . \quad{ }^{63}$ DeLillo, Point Omega, 30.
} 
"rendition." "Rendition" and "enhanced interrogation techniques" - which Elster knows to be criminal as he projects a future scenario in which "the administration's crimes" are tried in a Nuremberg/Eichmann-esque fashion with "men and women, in cubicles, wearing headphones" - are always undertaken, though, by "others." " ${ }^{4}$ Indeed, those who "ask pointed questions of flesh-and-blood individuals" "behind closed doors" are not the state but "finally others, still others." ${ }^{5}$ The implications of the state structure here are that it constitutes at once an international entity of political standing, but also contains its own alienated subnational Others, as with the novel's intraUS setting of a (metaphorically Iraqi) desert. This works, once more, bidirectionally, for this is how the United States is fictionally depicted here and it is also how the invasion of another sovereign power can be justified on the basis of terrorism; agents of terrorism are shown at once as Other (both nationally and culturally) and also as integral to the host. Indeed, Elster makes this explicit within his fictional article, mediating between the collective will of a power-structure nation and the subnational, terrorist component, as

$[\mathrm{t}]$ oward the end of the commentary he wrote about select current meanings of the word rendition - interpretation, translation, performance. Within those walls, somewhere in seclusion, a drama is being enacted, old as human memory, he wrote, actors naked, chained, blindfolded, other actors with props of intimidation, the renderers, nameless and masked, dressed in black, and what ensues, he wrote, is a revenge play that reflects the mass will and interprets the shadowy need of an entire nation, ours. ${ }^{66}$

What is, I hope, clearly emerging here is that there are several not-alwaysharmonious frameworks at play in DeLillo's works and in the discussion of terrorism, Iraq and the Cold War: a career-length framework that complicates distinctions between state and terrorist, a formal stylistic framework of intratextual registers signalling intertextual reference, and linguistic frameworks of terminological legitimation. In each of these frameworks there is, I contend, an element of contradiction, of bidirectionality that must be evaluated for a final political critique of DeLillo's aesthetic.

\section{CYCLICAL PRESENTS, FUTURE HISTORIES}

Interestingly, this bidirectionality is, itself, an aspect that resonates with the Cold War. As Thomas Hill Schaub has pointed out, "These improvisations on Cold War culture frequently take the forms of inverted order, repetition, and parataxis." 67 The ways in which this reconfigures the depiction of Iraq,

\footnotetext{
${ }^{64}$ Ibid., 33. $\quad{ }^{65}$ Ibid. $\quad{ }^{66}$ Ibid., 34.

${ }^{67}$ Thomas Hill Schaub, "Underworld, Memory and the Recycling of Cold War Narrative," in Olster, Don DeLillo, 69-82, 79.
} 
however, are more subtle; after all, DeLillo cannot rely on a historiographic approach to a history that has not yet been written in either mainstream or pluralized forms. Although there are, undoubtedly, other routes, three judgements will here be finally considered as a conclusion. Stemming from the theoretical framework laid out above these problematizing questions of DeLillo's narratives are, to briefly repeat: first, are atrocities amalgamated into an undifferentiated, homogeneous mass through metaphor? Second, are parallels between terrorism, the war on terror and the Cold War used to equate leftist thought with terrorism? And third, is the state recast as actor by small-state neocons and is this recasting, if present, framed in a mimetic, or ironic, mode?

The two atrocities framed in DeLillo's metaphor over his career, that the Cold War was a form of terrorism and that terrorism (leading to the Iraq War) is a continuation of the Cold War, certainly negate specific historical circumstances in the service of comparison. However, in Point Omega this is undertaken in favour of a particular, historicized understanding of the conditions that led to Iraq. In fact, significance lies not in a judgement of DeLillo's parallel, as though the author condoned this conflation, but rather in the truth that the bidirectionality of this representation says a great deal about America's self-image and, as DeLillo puts it, "need" for a continuing, statedriven, binary international conflict. In other words, ideas of strong statism advocated by right-wing figures in Point Omega are there to reflect a nostalgia for the continued, international Cold War. Right-wing figures, paradoxically, resist the (postmodern) plurality of the market claimed by Hardt and Negri through a desire for strong patriotic nation-statehood.

That said, DeLillo also points out that America contains its inherent Others and looks inward to see outward. This is most notably seen in the representation of foreign wars through the desert landscape that continually evokes the phrase "Operation Desert Storm." While Point Omega remains a text that runs the risk of reinscribing an exceptional America that contains all Others, this containment becomes more than simply an exercise in literary colonialism, but rather a mirror. DeLillo's novel may look inwards, but the reflection cast in the glass seems to be an image from outside. Such an exercise in seeing darkly is a valuable literary technique because it allows DeLillo's bidirectional setup to gain ethical purchase. Cultural difference is both enshrined and erased; America is the isolated focus but within America lies alterity. This bidirectionality, framed here through the image of looking in a rearview mirror, a rear window perhaps, is the adept mechanism through which Point Omega's trans-temporal metaphors at once conflate and distance; negotiate historical and cultural specificity; and, more importantly, represent the mentality that relativizes and analogizes. To rephrase: DeLillo's strong statists only achieve self-recognition by seeing the reflected metaphorical 
damage of Iraq within their own nation, within their own deserts, which is immediately more permeable than an exceptionalist rhetoric would allow.

In order to ask next whether DeLillo's text equates leftist thought with terrorism it is necessary to undertake some stratification of the intra- and extratextual voices in the novel. DeLillo does not give a straightforward political assessment of Richard Elster. Admittedly, Elster is a member of the New School and, in his description of the torture chamber as a drama populated by actors with props of intimidation, he approaches dangerously close to the Divine Marquis. ${ }^{68}$ Simultaneously, though, his voice echoes the disembodied narratorial, prophetic tone of DeLillo's other texts, making it hard to ascertain whether Elster speaks for the novel. On the other hand, Jim provides a counterpoint by invoking the name of the Dada-inspired anarchist collective "Up Against the Wall Motherfuckers," as the name of his proposed interview with Elster, thereby implying a violence in his response to Elster's involvement in the planning of the statist conflict, even if this does itself echo Underworld. It is not coincidence that DeLillo uses film, for it affords us the use of a fortuitous phrase: the film will involve the military adviser being shot against the wall.

The tension here, then, is that there is a consistent threat of "leftist violence" (terrorism) throughout the text, but the novel seems to be mediated by Elster, despite the fact that it is Jim narrating. The nostalgic back-reference to other novels in DeLillo's corpus and the Cold War analogies seem to reenforce this; the novel, as a whole, is oddly aligned with Elster's worldview, even though he is not the central voice. This is not to say that DeLillo is aligned with this view and I would suggest, instead, that this is one of DeLillo's coups: that the words of leftist thought could be so mediated in the description of right-wing thought by that very right-wing discourse has a certain mimetic quality.

Finally, leading on from these questions of diegesis, to ask where DeLillo situates the state and neoconservativism is, perhaps, to miss the point of Point Omega. The state - like Jessie, the neoconservative's daughter - has gone missing in the desert, now only a haunting figure whose advocates wish it as simultaneously a presence and an absence, both inside and outside. Indeed, the text, through different layers of voicing, reminiscent of W. G. Sebald's constant reinflections in Austerlitz, does not allow us to evaluate this stance but instead merely presents the bivalent fluctuations of state and individual in alternation.

To draw these threads together to posit a conclusion, it is clear that Point Omega, Don DeLillo's shortest novel, is a text that is centred around the

${ }^{68}$ DeLillo, Point Omega, 50. 
spectrally present Iraq War. It is also, however, a multilayered conflation of and mediation between stylistic genres. The text makes specific back-reference to the Cold War in Underworld, in which subnational notions of terrorism are placed into direct parallel with this quasi-virtualized past conflict. Point Omega itself situates the Iraq War, in both its explicit narrative content and its aesthetic form, between state action (war) and non-state actors (terrorism/ abduction), fluctuating between the massive (Underworld) and the individual (Point Omega). This novel can be read as a text of transition to a new mode of warfare in which the massive state is no longer the central player. It can also, though, be read as a text that loops, that rehistoricizes, that builds patterns both literary-taxonomical and sociohistorical, a text that reruns the film of its antecedents, Running Dog, Libra and, of course, Underworld. DeLillo can be read as implying that the nature of international conflict is now changing, but he can also be seen as referencing the past (his own, literary past) and implying the cycle. It is for good reason, after all, that Elster - whom we must read as a complexly placed literary figure and not the voice of the novel - calls "these nuclear flirtations we've been having" "Little whispers." ${ }^{69}$ It is perhaps true, in regard to the first reading, that Elster truly believes that "[w]e're all played out." ${ }^{\circ}$ It may be, as Derrida argues in Rogues, that the pre-9/ I I, Cold War location of the enemy within nation-states is breaking down. ${ }^{71}$ On the other hand, the historical cycle that DeLillo implies through his comparative intertextual reference is far less easy to dismiss and the problems of relativism that this introduces seem only to be solved in recourse to a faith in the absolutist experience of the individual. Indeed, the core of DeLillo's latest novel lies in the disappearance of an individual, an experience that is never told, even as it is framed by a relativistic depiction of war and violence.

While this thematic link to Iraq might give the impression that Point Omega is to be read as a highly politicized, committed novel on even the surface level of its narrative, David Cowart succinctly characterises this differently in his cleverly titled article "The Lady Vanishes": "Though he foregrounds the spiritual crisis of an apologist for the Second Gulf War, DeLillo deflects problems of immediate political legitimacy toward larger, less topical questions of a civilization's decline. He perpends the prospect of an omega point for the American empire." ${ }^{22}$ While, therefore, DeLillo may claim that "the novel itself is not at all political," this is only superficially true..$^{73}$ The novel may not be condemnatory in its tone or theme regarding

${ }^{69}$ Ibid. $\quad{ }^{70}$ Ibid.

${ }^{71}$ Michael Naas, Derrida from Now On, Perspectives in Continental Philosophy (New York: Fordham University Press, 2008), I $24 . \quad \quad{ }^{72}$ Cowart, "The Lady Vanishes," 32.

${ }^{73}$ Don DeLillo, "A Conversation with Thomas DePietro," Barnes \& Noble Review, I Feb. 20 10, at http://bnreview.barnesandnoble.com/t5/Interview/Don-DeLillo/ba-p/2 I 44. 
those responsible for the Iraq War, but the cyclical nature of this Gibboninflected, intra-US imperial-decline interpretation has, I contend, implications for how we read DeLillo on Iraq and on terrorism in Point Omega and across his oeuvre.

What, though, of aesthetics and ethics? In this narrowing of focus that nonetheless includes DeLillo's references to his own canon, Point Omega still glosses tragedy, as a cast back to Bataille, but his novels are seeking a course towards self-obliteration and recognition of nonknowledge: "Every lost moment is the life. It's unknowable except to us, each of us inexpressibly, this man, that woman." 74 DeLillo's novels also relativize specific tragedy and conflict, inescapably in Adornion thinking, mostly through this same intertextual reference to the author's own canon. Indeed, though, this is among the fundamental tensions of this novel: regardless of the focus on narrowing and individual experience, regardless of the final specificity placed upon the event, there are, certainly in DeLillo's continuing worlds of relativizing macro-histories, "Too many goddamn echoes."75

\footnotetext{
${ }^{74}$ DeLillo, Point Omega, 63.

${ }^{75}$ Ibid., 2 I.
} 